\title{
Ethnobotanical Knowledge Complexity in a Conservation Area of Northern Uruguay: Interlocutors-Medicinal Plant Network and the Structural Patterns of Interaction
}

\author{
Elena Castiñeira Latorre* ${ }^{*}, 2$, Andrés Canavero $^{2}$, and Matías Arim ${ }^{2}$ \\ ${ }^{1}$ Laboratorio de Etnobotánica y Botánica Aplicada, Facultad de Ciencias Naturales y Museo, Universidad \\ Nacional de La Plata, 1900 La Plata, Buenos Aires, Argentina \\ ${ }^{2}$ Departamento de Ecología y Gestión Ambiental, Centro Universitario Regional del Este (CURE), \\ Universidad de la República, Maldonado, Uruguay \\ *Corresponding author; e-mail: elencasti@gmail.com
}

\begin{abstract}
With the aim of generating a strategy for biocultural conservation, we explore the structure and robustness of the botanical medical systems in the Biosphere Reserve "Bioma Pampa-Quebradas del Norte," Uruguay, combining ethnobotanical hypotheses and network theory. We report a heterogeneous distribution of knowledge of medicinal plants with a potential limit to the individual knowledge (truncated-power-law). The robustness analysis in the face of alternative potential scenarios of system degradation indicates that the ethnobotanical system presents a high level of resistance to the loss of agents and medicinal plants species, but also a nonlinear response with a threshold of degradation after which an abrupt collapse in system structure is expected. To counter these threats at the Biosphere Reserve, we propose to promote ethnobotanical knowledge transmission and sustainable development in rural areas, and to encourage the development of strategies for the conservation of medicinal plants.
\end{abstract}

Con el objetivo de generar una estrategia de conservación biocultural, exploramos la estructura y la robustez del sistema botánico médico en la Reserva de Biosfera "Bioma Pampa-Quebradas del Norte," Uruguay, combinando hipótesis etnobotánicas y teoría de redes. Reportamos una distribución heterogénea del conocimiento sobre las plantas medicinales con un límite potencial del conocimiento individual (ley poder-truncada). El análisis de robustez frente a posibles escenarios alternativos de degradación, indica que el sistema etnobotánico presenta un alto nivel de resistencia a la pérdida de agentes y plantas medicinales. También se observa una respuesta no lineal con un umbral de degradación, después del cual se produce un colapso abrupto de la estructura del sistema. Para contrarrestar estas amenazas en la Reserva de Biosfera, proponemos promover los procesos de transmisión de conocimiento etnobotánico y el desarrollo sostenible en áreas rurales, así como alentar el desarrollo de estrategias para la conservación de plantas medicinales.

Key Words: Botanical medical systems, Resilience, Knowledge erosion, Medicinal plants, Network analysis, Biocultural conservation.

\footnotetext{
${ }^{1}$ Received 24 November 2018; accepted 8 April 2020; published online 6 May 2020
}

Received 23 November 2018; accepted 18 March 2020.

\section{Introduction}

Ethnobotanical science has identified and reported medical systems where medicinal plants are the main source of primary health care in communities (Albuquerque et al. 2015; WHO 2013). In countries with weak economies, these botanical medical systems frequently are the only source of health care (WHO 2013) and, despite their importance, they 
also present a high risk of biological and cultural erosion (Gavin et al. 2015). These medical systems link knowledge, behaviors, and beliefs about medicinal plants (Gaoue et al. 2017; Santoro et al. 2015). An emerging property of these systems is the biocultural diversity, arising from the "inextricable link" between the biological environmental and the human cultural component (Maffi 2005, 2007). It has been proposed that conserving this biocultural diversity is essential to increase the resilience of these systems in the face of disturbances due to both the loss of species and the erosion of knowledge (Gavin et al. 2015; Maffi 2005, 2007; Reyes-García et al. 2013).

Uruguay is considered an emerging country in Latin America, with access to industrialized medicines reaching most of the territory and population (Cardona et al. 2013). However, mixed systems incorporating medicinal plants for the health care are frequent in Uruguay (Castiñeira Latorre et al. 2018) and neighboring countries (e.g., Hilgert 2009; Medeiros et al. 2016). The Department of Rivera has a rich pharmacopeia associated with a vast cultural heritage coming from the amalgamation of various Amerindian, European, and African cultures (Barrios Pintos 1963, 1990; Bonilla et al. 2004; Curbelo 2003; González and Rodríguez Varese 1990; Pi Hugarte 2014). In addition, Rivera is one of the richest biodiversity areas in the country (Brazeiro 2015; Castiñeira Latorre et al. 2018; Soutullo et al. 2013). This cultural and natural patrimony is endangered because it is immersed in one of the most socially and economically deprived regions in the country. This area is subject to extensive agriculture development (e.g., agricultural forestry), which promotes rural depopulation and environmental degradation. Thus, it is essential to record knowledge about medicinal plants (Cunningham 2001).

To unravel the complexity of these plant-based medical systems, network theory provides a promising framework, allowing the formalization and evaluation of sound hypotheses of ethnobotanics (Borgatti et al. 2013; Cavechia et al. 2014). To this aim, ethnobotanical systems can be represented as bipartite networks where interlocutors and medicinal plants are represented as two different kinds of nodes connected by the used plants (Cavechia et al. 2014; Diaz-Reviriego et al. 2015). In this article we focus on two properties of ethnobotanical networks: degree distribution and robustness to the loss of elements (see Burgos et al. 2007; Pascual and Dunne 2006), connecting these features with sound hypotheses of knowledge transmission. Degree distribution - the distribution frequency of the number of links per species or interlocutor-may detect the effect of three alternative ethnobotanical hypotheses of knowledge transmission (Pochettino and Eyssartier 2014; Santoro et al. 2018; Soldati 2013; Soldati and Albuquerque 2016). A power-law degree distribution-characterized by few nodes with several links and few links to most other nodes-indicates that most of the interlocutors report few medicinal plants and few interlocutors report a disproportionally large number of plants or uses. This pattern is congruent with the parentoffspring transmission of knowledge, which is concentrated in few persons (e.g., medical system based in traditional healers; Ferreira Júnior et al. 2011; Soldati 2015; Suárez 2014). A second potential distribution-the exponential decay-is expected when most interlocutors have a similar average knowledge, without large deviation, of the use of few or many medicinal plants. This pattern may originate from a combination of the different mechanisms proposed for knowledge transmission (i.e., vertical, horizontal, and oblique), which may homogenize the population's knowledge (Santoro et al. 2018; Soldati 2015). The third pattern-a truncated power-law distribution-first follows a power-law distribution but decays to an exponential distribution at a large number of connections. In this case, the predominant pattern of transmission may correspond to the vertical, without excluding the action of other processes (e.g., horizontal and oblique, see Pochettino and Eyssartier 2014; Santoro et al. 2018; Soldati 2013, 2015; Soldati and Albuquerque 2016). In addition, a restricted number of species or interlocutors constrain the maximum number of links that a node can present, determining the transition from a power-law to an exponential decay in the number of connections. This restriction could be a consequence of human cognitive limitations (i.e., memory), and/or of the environmental availability of medicinal plants (Boyd et al. 2011; Rendell et al. 2010; Sousa et al. 2016).

Network analysis also allows for the experimentation of the robustness of the ethnobotanical system in response to the loss of interlocutors or medicinal plants (Cavechia et al. 2014; Kareiva and Marvier 2015). Three scenarios of interlocutors removal were proposed (Brito et al. 2017): a) community aging determines the loss of interlocutors who are holders of knowledge-with more connections to plants and uses; b) age-structured 
knowledge and weak elder-young transmission determine that young people abandon botanical medical systems-loss of interlocutors with lower connections; and c) depopulation in rural areas and the social abandonment of plant uses determine a random removal of interlocutors independent of their previous knowledge-in a random sequence. The same reasoning was applied for the loss of medicinal plants (Brito et al. 2017; Calvet-Mir et al. 2016; Mathez-Stifel et al. 2012; Quilan and Quilan 2007; Reyes-García et al. 2013).

In this study we analyze the structure and robustness of the botanical medical systems in the Biosphere Reserve "Bioma Pampa-Quebradas del Norte," Uruguay, combining ethnobotanical hypotheses and network theory (Hamilton and Plenderleith 2003). We report a heterogeneous distribution of knowledge of medicinal plants with a potential limit to the individual knowledge (truncated-power law). The robustness analysis in the face of alternative potential scenarios of system degradation indicates that the ethnobotanical system presents both a high level of resistance to the loss of agents and also a nonlinear response with a threshold of degradation after which an abrupt collapse in system structure is expected.

\section{Methods}

\section{STUdy AREA}

The study area was the Biosphere Reserve "Bioma Pampa-Quebradas del Norte," Uruguay. This area is considered one of the most important reservoirs of biodiversity in Uruguay (Brazeiro 2015; Soutullo et al. 2013). It presents a system of flat hills with high environmental heterogeneity and plant diversity (Chebataroff and Zavala 1975). The predominant plant species corresponding to the Pampas is represented by the families Asteraceae, Fabaceae, Orchidaceae, and Poaceae. Other species are associated with a relict of Atlantic subtropical forests unique in the country (Brussa and Grela 2007). The average temperature of Uruguay is $17.5{ }^{\circ} \mathrm{C}$ and the average annual rainfall is $1300 \mathrm{~mm}$, typical of a temperate or subtropical climate, which, following the classification of $\mathrm{K}$ ppen, corresponds to the category Cfa (Kottek et al. 2006; Rubel and Kottek 2010).

The population is framed in a pluricultural context (sensu Martínez et al. 2006). This is integrated by an Amerindian cultural component originating from descendants of native peoples (mainly Guaraní) and "Creole" (in Spanish: "Criollos") from European immigrants and African slaves (Barrios Pintos 1963, 1990; Bonilla et al. 2004; Curbelo 2003; González and Rodríguez Varese 1990; Pi Hugarte 2014). Currently, 100,000 people populate the department of Rivera, concentrating mostly in the city of the same name, with a quarter of habitants in semi-rural and rural areas. These small-scattered areas host family farms dedicated to small-scale agricultural and livestock activity (Rodríguez-Miranda 2010, 2015). The family production units develop chard, tobacco, and watermelon crops with minimal resources and with access to product markets in the nearest populated centers. The activity is intended for self-consumption and sale of surplus without capital accumulation (Nolla and de Vargas 2010; Rodríguez-Miranda 2010, 2015). Other productive activities in the area correspond to multinational companies, related to the implantation of pine and eucalyptus forests.

This study was carried out using the "snowball sampling" method in rural and urban areas of the Biosphere Reserve, performing 44 semi-structured interviews (Newman 2010; Noy 2008). The interlocutors who participated in the interviews were informed of the ethical formal aspects established by the International Society of Ethnobiology (ISE 2014). Interviews were conducted using a set of questions about medicinal plant knowledge (Albuquerque et al. 2014; Cunningham 2001; Newman 2010; Noy 2008). To know the medicinal plant list and uses of people at the study area, we developed semi-structured interviews that included information about the interlocutors (e.g., name, age, place of birth, residence, work activity). Then the interview was guided by a set of questions about which medicinal plants were used for the maintenance and care of his or their family health. About these medicinal plants, we also ask how and where did they get them (e.g., harvest sites, bought in markets) (Castińeira Latorre et al. 2018). From the characterization and designation that interlocutors performed about the ailments and treatments associated with each medicinal plant (emic categories) (Beiersmann et al. 2007), an own categorization of the ailments was generated (etic categories) considering the classification based on Western medicine (Albuquerque et al. 2014; Santoro et al. 2015). The taxonomic identity of plant species reported by interlocutors was corroborated at two levels: 1) using the participant observation technique/strategy at harvest sites, courtyards, and 
gardens, and also observing the medicinal plants bought in markets (Albuquerque et al. 2014), and 2) consulting the following databases: Tropicos (www.tropicos.org), Plants Database (USDA, www.plants.usda.gov), Reflora (www.floradobrasil. jbrj.gov.br), and the Catalog of Vascular Plants of Southern Cone Flora Darwinion Botanical Institute (IBODA,www.darwin.edu.ar). Voucher specimens were collected for deposit in the Herbarium of the National Museum of Natural History of Montevideo (MNHN) (Bennett and Balick 2014) (for more details see Castińeira Latorre et al. 2018).

\section{DATA ANALYSIS}

The network analyses were carried out by generating a bipartite affiliation matrix composed by interlocutors (matrix rows) and medicinal plants (matrix columns); the matrix was filled with $1 \mathrm{~s}$ if a plant was reported by an informer and $0 \mathrm{~s}$ otherwise (Newman 2010). Degree distribution was estimated fitting three distributions to the cumulative number of links (Pascual and Dunne 2006): exponential $\left[P(k) \simeq e^{-k}\right]$, power law $\left[P(k) \simeq k^{-\gamma}\right]$, and truncated power law distribution $\left[P(k) \simeq k^{-} e^{-k / k_{c}}, k_{c}\right.$ is the critical value where the distribution departs from the power law]. The Akaike information criterion (AIC) was used for model selection, where the models with the lowest AIC were selected and differences greater than 2.0 were considered significant (Hilborn and Mangel 1997; Johnson and Omland 2004; Richards 2005).

The robustness of the ethnobotanical network to the extinction of species and interlocutors was evaluated in three scenarios (following Brito et al. 2017): 1) sequential deletion from the most connected to the least connected agents; 2) removal from the least connected to the most connected agent; and 3) random removal of agents. The robustness analysis is as follows: i) agent of one of the two kinds (plants or interlocutors) is removed; ii) the number of the other kind of agent with at least one connection is registered; iii) steps i and ii are repeated until no more agents to remove are available; iv) the proportion of disconnected nodes (plants or interlocutors) is related with the proportion of removed agents (interlocutors or plants) (see Memmott et al. 2004). Burgos et al. (2007) developed the Robustness index, $R$, where they proposed that the area under the curve relating these two proportions (proportion of removed agents vs. proportion of disconnected nodes) is considered as a measure of the robustness of the entire system. $R$ values close to one speak of a robust system to primary extinctions and values close to zero would indicate a system vulnerable to disturbances (see Burgos et al. 2007; Mello et al. 2011; Memmott et al. 2004; Pascual and Dunne 2006). The functions second.extinct, slope. Bipartite and robustness of the "bipartite" package (Dormann et al. 2008, 2009) in the R system ( $R$ Core Team 2017) were used in these analyses.

\section{Results}

The bipartite network was composed of 44 interlocutors and 159 medicinal plants (Fig. 1). Interlocutors have an average use of 18.3 medicinal plants. The most named species were Achyrocline satureioides (Lam.) DC. (39 interlocutors), Stenachaenium campestre Baker (25 interlocutors), Matricaria recutita L. (22 interlocutors), Malva sylvestris L. (21 interlocutors), Aloysia citrodora $\mathrm{Pa}-$ láu, and Baccharis articulata (Lam.) Pers. (20 interlocutors). The degree distribution of the bipartite network nodes follows a truncated power law distribution (Table 1 and Fig. 2). Truncation of the power law distribution takes place at the use of 30 species by interlocutors (Fig. 2). In relation to the analysis of network robustness to alternative scenarios of nodes deletion, the ethnobotanical network presented a high resistance to the removal of nodes with an average robustness of 0.78 (Range $=0.59$ 0.99) (Fig. 3). However, large differences were detected among explored scenarios (Fig. 3).

\section{Discussion and Conclusion}

The botanical medical systems are considered a source of health care of central importance in countries with weak economies (WHO 2013). At the Biosphere Reserve "Bioma Pampa-Quebradas del Norte," Uruguay, a mixed health care system is used, integrating official medicine with a botanical medical system (Zank and Hanazaki 2017). Here we report a complex network of plants and users, characterized by truncated power law distribution in the number of connections and a robust structure in the face of species and interlocutor deletions. However, the strong nonlinear relationship between deletion of species or interlocutors and consequent loss of agents indicates that, after a threshold in the deterioration of the system is achieved, its precipitous collapse may follow; a result that is particularly 


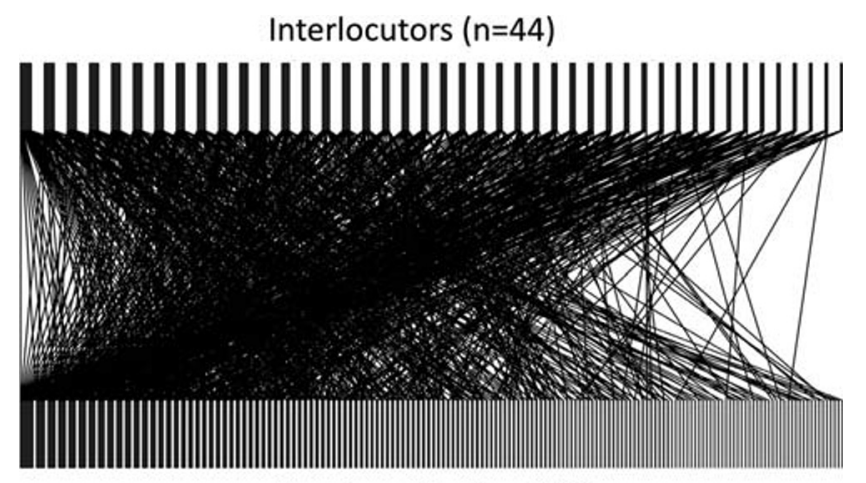

Plant species $(n=159)$

Fig. 1. Bipartite network representing the use of plant species (lower boxes) by interlocutors (upper boxes)

important considering the ongoing expansion of agricultural forestry and depopulation, which may put at risk the traditional knowledge system (Kareiva and Marvier 2015). Network analysis, which is applied to untangle several ecological relationships (Bascompte and Jordano 2007; Cavechia et al. 2014; Pascual and Dunne 2006), provides here a complementary approach for the description of ethnobotanical systems and the formal evaluation of sound hypotheses.

Strategies for biocultural conservation require understanding of the distribution and transmission of knowledge in the community (Gavin et al. 2015; Maffi 2007). We include the network analysis to unravel the ethnobotanical complexity of the botanical medical systems (Cavechia et al. 2014; DiazReviriego et al. 2015; Zank and Hanazaki 2016). The ethnobotanical knowledge pattern corresponds to a truncated power-law distribution. This pattern shows that knowledge is mainly contained by a small group of people (e.g., knowledgeable, healers) but they share their knowledge with the other members of the community. In this sense, we can assume that, although the vertical transmission of knowledge has a strong impact on the system, the other types of transmission must be operating too (i.e., horizontal and oblique) (Pochettino and Eyssartier 2014; Soldati 2013, 2015; Soldati and Albuquerque 2016; Soldati and Santoro et al. 2018). This pattern contrasts with systems centered on healers, where ethnobotanical knowledge is concentrated in them and horizontal and oblique transmission tend not to occur (Ferreira Júnior et al. 2011; Soldati 2015; Suárez 2014). In this work, vertical transmission may also be associated with family contexts in isolated rural areas where a greater knowledge and potential use of native medicinal species with the indigenous cultural origin is detected (Castińeira Latorre et al. 2018; González and Rodríguez Varese 1990; Lozada et al. 2006). We inferred that horizontal and oblique knowledge transmission are operating given that the

TABle 1. EVAluATION OF THE ADJUSTMENT OF THE EXPONENTIAL, POWER LAW, AND TRUNCATED POWER LAW MODELS FOR THE NETWORK DEGREE DISTRIBUTION. “AGENT” REFERS TO THE KIND OF NODE ANALYZED (SPECIES OR INTERLOCUTORS). EXPONENTIAL, POWER LAW, AND TRUNCATED POWER LAW MODELS WERE COMPARED. AIC, VALUE OF THE AKAIKE INFORMATION CRITERION, THE LOWER VALUE INDICATES THE MODEL MORE CONGRUENT WITH OBSERVATIONS. DiFFERENCES IN AIC LARGER THAN TWO UNITS ARE STATISTICALlY SIGNIFICANT. A TRUNCATED POWER-LAW DISTRIBUTION IS STRONGLY SUPPORTED FOR THE DISTRIBUTION OF NUMBER OF LINKS FOR PLANT SPECIES AND FOR INTERLOCUTORS

\begin{tabular}{llr}
\hline \hline Model & Agent & AIC \\
\hline exponential & species & $-91,68$ \\
power law & species & $-58,89$ \\
truncated power law & species & $-162,02$ \\
exponential & interlocutors & $-38,38$ \\
power law & interlocutors & $-15,86$ \\
truncated power law & interlocutors & $-75,16$ \\
\hline
\end{tabular}




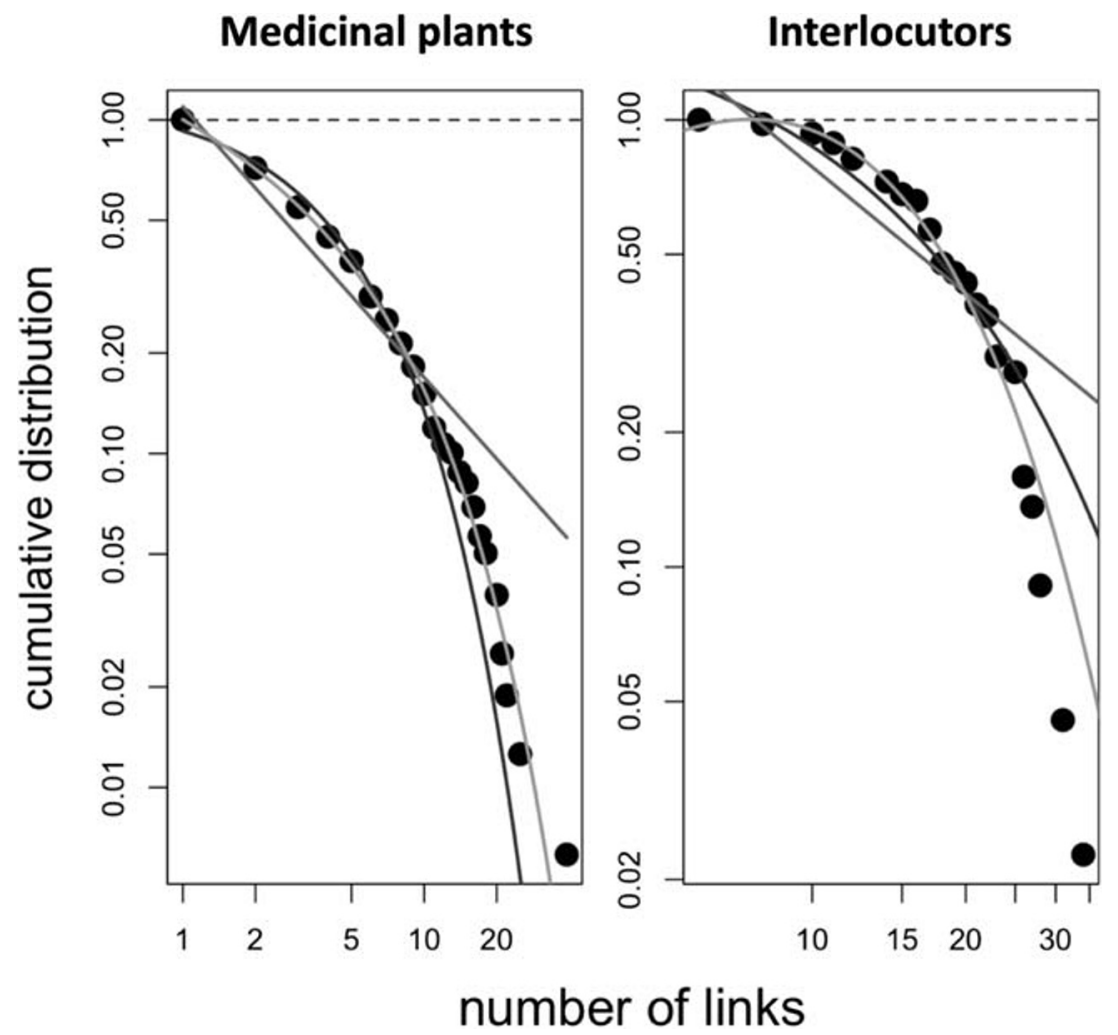

Fig. 2. Distribution of number of links along plants (left panel) and interlocutors (right panel). The black, dark, and light gray line refers to the exponential, power-law, and truncated power-law models respectively. Fitting performance in Table 1

community in general possesses an important degree of shared knowledge of medicinal plants. This idea is reinforced by a pluricultural context, which promotes and facilitates these transmission phenomena (Pochettino and Eyssartier 2014; Vandebroek and Balick 2012). In particular, the oblique transmission from "one to many" generates the inclusion of variation through the means of communication (e.g., textbooks, radio, television, internet) (Hewlett and Cavalli-Sforza 1986; Leonti 2011; Soldati and Albuquerque 2016). The occurrence of a significant number of alien plant species at local pharmacopeia shows the importance of this transmission type in pluricultural contexts (Castińeira Latorre et al. 2018; Medeiros et al. 2012).

Returning to the knowledgeable interlocutors, there is also a relevant phenomenon in our results. The high number of medicinal plants they reported presented also a limit (around 30 species) that could be attributed to different causes: cultural limitations
(Reyes-García et al. 2013); socio-genderdemographic heterogeneity (Müller et al. 2015); medicinal plants environmental availability (Albuquerque and Oliveira 2007; Medeiros and Albuquerque 2015); and/or a human cognitive restriction (i.e., memory) (Boyd et al. 2011; Rendell et al. 2010; Sousa et al. 2016). Cultural limitations could be invoked when a certain portion of the population does not use a medicinal plant because they do not have the knowledge of how to use it. Low diversity of use of medicinal plants can be generated because knowledge is compartmentalized between different social groups (e.g., by gender, age). These first two causes, although they may be operating, do not seem to be the main mechanism since the transmission of ethnobotanical knowledge between different social groups seems to be a common pattern of the system studied (see the previous paragraph). The third cause, environmental availability, would be unlikely, because the area presents a high botanical diversity, where the supply of 


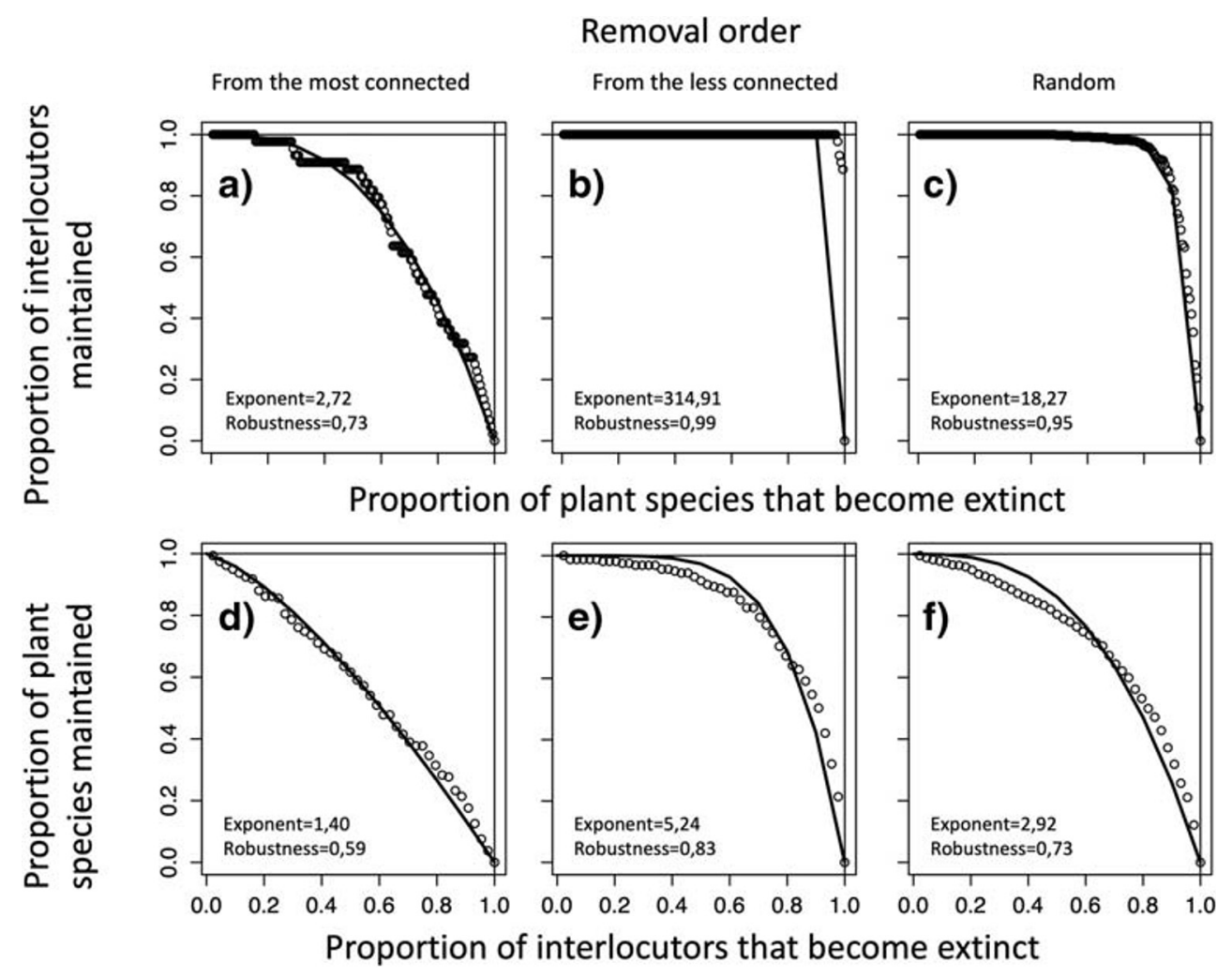

Fig. 3. Evaluation of network robustness to deletion of medicinal plants (upper plots) and interlocutors (lower plots). Three scenarios of agents deletion were considered: i) from the more to the least connected agents (A and D); ii) from least to the more connected agents (B and $\mathrm{E})$; and iii) random deletion of agents ( $\mathrm{C}$ and $\mathrm{F})$. Robustness is a [0-1] index corresponding to the area under the curve ( 0 represents a system with low resistance that collapses after the loss of one species and 1 represents a robust system that only collapses with the loss of the last species)

therapeutic options would be high as well. Therefore, the human cognitive restriction would have the greatest sustenance. However, the species richness of local pharmacopeia offers vast therapeutic options. In this sense, the botanical medical system reflects the cumulative body of knowledge acquired through the individual perception of nature and knowledge transmission (i.e., social learning, Boyd et al. 2011; Ferreira Júnior et al. 2015). Furthermore, the interlocutors individually, even the most knowledgeable ones, have a limit on the number of medicinal plants that they potentially use, while, at the community level, the whole botanical medical system offers a wide range of therapeutic alternatives (Henrich and Broesch 2011; Rendell et al. 2010).

The removal experiments report a system that presents a robust behavior against different degrees of disturbance within a certain range of interlocutors and medicinal plant loss. However, there are important differences in the three robustness patterns. When the ethnobotanical knowledge is eroded from the most connected agents-e.g., elderly people with a greater amount of information, and most used species- the system shows low robustness because of the loss of the most connected nodes. In this sense, the knowledge transmission pattern and the biological conservation of most used medicinal plants are key attributes to promote resilience (Brito et al. 2017). However, this scenario can be transformed into another scenario associated with the rural exodus, which mostly involves young people (i.e., less connected nodes). This population age class tends to have less knowledge about medicinal plants and, in consequence, the ethnobotanical system resilience diminishes more slowly with this loss (Brito et al. 2017; Rodríguez-Miranda 2010, 2015). The last scenario presents a random deletion of interlocutors and medicinal plants. In the first 
case, the loss of people could be the consequence of an epidemic, war, or famine. In the second case, the species extinction could be associated with the developmental changes in rural areas (e.g., agroindustry of soybean crops and afforestation) (Brito et al. 2017; Rodríguez-Miranda 2010, 2015). This scenario presents an intermediate robustness pattern between the first two but is dominated by a strong nonlinear response to system degradation.

To develop proper management strategies for biocultural conservation, the structural characteristics of the botanical medicinal systems have to be considered. In our case, it is a pluricultural system with knowledgeable people who share their knowledge within the community. This feature could be considered an opportunity for management. In short, the management strategy should promote the transmission of local ethnobotanical knowledge, including the recognition of knowledge, validation of it socially, and revaluation of it culturally (LagosWitte et al. 2011). It is also important to promote the permanence of the rural population and to avoid the modification of the medicinal plants habitats since it is in these rural areas where there is a higher incidence of traditional knowledge (mainly Guaraní) (Castiñeira Latorre et al. 2018). The normative framework of the UNESCO Biosphere Reserve "Bioma Pampa-Quebradas del Norte" (https://en. unesco.org/), presents opportunities to promote biocultural conservation, improving the resilience of the botanical medical systems and reinforcing the cultural traditions of the inhabitants of this rural areas (Gavin et al. 2015; Maffi 2007; Ramirez 2007; Reyes-García et al. 2013).

In this work, we used a methodology that not only turned out to be an appropriate tool to associate network patterns to transmission processes of ethnobotanical knowledge, but also to explore the ethnobotanical system resilience (Cavechia et al. 2014; Diaz-Reviriego et al. 2015; Zank and Hanazaki 2016). The truncated pattern for medicinal plants supports the idea that knowledge is shared in the community and maintained by the dynamics of social learning. Moreover, this ethnobotanical knowledge is influenced by the high biodiversity environment and the pluricultural context in which it is produced and shared (Albuquerque and Oliveira 2007; Boyd et al. 2011; Pochettino and Eyssartier 2014). The ethnobotanical system presents a large robustness to the loss of interlocutors or medicinal plants (Cavechia et al. 2014; Kareiva and Marvier 2015), a robustness that may be diminished after reaching degradation thresholds. These threats can be countered by promoting knowledge transmission and sustainable development in rural areas, and implementing medicinal plants management conservation programs. The study area probably represents one of the most relevant reservoirs of biocultural diversity in Uruguay. Consequently, management strategies oriented to the conservation of the botanical medical systems at the UNESCO Biosphere Reserve "Bioma Pampa-Quebradas del Norte" are urgently needed if its patrimonial value and the well-being of the community are to be promoted (Cunningham 2001).

\section{Acknowledgments}

This article would not have been possible without the collaboration of the residents of the Biosphere Reserve "Bioma-Pampa Quebradas del Norte, Rivera." This research was financed by the National Agency for Research and Innovation of Uruguay (ANII), within the framework of the $\mathrm{Ph}$.D scholarship granted to ECL. Other economic support was provided by the Rufford Small Grant and the Swiss Embassy in Uruguay. ECL is grateful for the careful reading of María Leila Pochettino. We also want to thank Orou Gaoue for helpful comments and revision that have significantly improved the manuscript.

\section{Literature Cited}

Albuquerque, U. P., F. C. C. Luiz Vital, R. F. P. D. Lucena, and R. R. N. Alves. 2014. Methods and techniques in ethnobiology and ethnoecology. New York: Humana Press.

Albuquerque, U. P., P. M. Medeiros, and A. Casas, eds. 2015. Evolutionary ethnobiology. Switzerland: Springer.

Albuquerque, U. P. and R. F. D. Oliveira. 2007. Is the use-impact on native caatinga species in Brazil reduced by the high species richness of medicinal plants? Journal of Ethnopharmacology 113(1): 156-170.

Barrios Pintos, A. 1963. Rivera en el ayer. De la crónica a la historia. Uruguay: Editorial Minas.

—. 1990. Rivera. Una historia diferente. Tomo II. Montevideo: Ministerio de Educación y Cultura.

Bascompte, J. and P. Jordano. 2007. Plant-animal mutualistic networks: The architecture of 
biodiversity. Annual Review of Ecology, Evolution and Systematic 38: 567-593.

Beiersmann, C., A. Sanou, E. Wladarsch, M. De Allegri, B. Kouyaté, and O. Müller. 2007. Malaria in rural Burkina Faso: Local illness concepts, patterns of traditional treatment and influence on health-seeking behaviour. Malaria Journal 6: 106.

Bennett, B. C. and M. J. Balick. 2014. Does the name really matter? The importance of botanical nomenclature and plant taxonomy in biomedical research. Journal of Ethnopharmacology 152(2014): 387-392.

Bonilla, C., B. Bertoni, S. González, H. Cardoso, N. Brum-Zorrilla, and M. Sans. 2004. Substantial native American female contribution to the population of Tacuarembó, Uruguay, reveals past episodes of sex-biased gene flow. American Journal of Human Biology 16(3): 289-297.

Borgatti, S. P., M. G. Everett, and J. C. Johnson. 2013. Analyzing social networks. Sage Publications, Ltd.

Boyd, R., P. J. Richerson, and J. Henrich. 2011. The cultural niche: Why social learning is essential for human adaptation. Proceedings of the National Academy of Sciences 108 (Supplement 2): 10918-10,925.

Brazeiro, A. 2015. Eco-regiones de Uruguay: Biodiversidad, presiones y conservación. Aportes a la estrategia nacional de biodiversidad. Montevideo: Facultad de Ciencias.

Brito, C. C., T. C. Silva, U. P. Albuquerque, M. A. Ramos, W. S. Ferreira Júnior, F. N. Barros, E. M. C. Neto, and P. M. Medeiros. 2017. The use of different indicators for interpreting the local knowledge loss on medical plants. Revista Brasileira de Farmacognosia 27(2): 245-250.

Brussa, C. and I. Grela. 2007. Flora arbórea del Uruguay. Con énfasis en las especies de Rivera y Tacuarembó. Montevideo: COFUSA.

Burgos, E., H. Ceva, R. P. J. Perazzo, M. Devoto, D. Medan, M. Zimmermannd, and A. M. Delbue. 2007. Why nestedness in mutualistic networks? Journal of Theoretical Biology 249: 307-313.

Calvet-Mir, L., C. Riu-Bosoms, M. GonzálezPuente, I. Ruiz-Mallén, V. Reyes-García, and J. L. Molina. 2016. The transmission of home garden knowledge: Safeguarding biocultural diversity and enhancing social-ecological resilience. Society and Natural Resources 29(5): 556-571.

Cardona, D., L. D. Acosta, and C. L. Bertone. 2013. Inequidades en salud entre países de
Latinoamérica y el Caribe (2005-2010). Gaceta Sanitaria 27(4): 292-297.

Castiñeira Latorre, E., A. Canavero, and M. L. Pochettino. 2018. Analysis of the ethnobotanical knowledge network for a priority area for biocultural conservation, Rivera, Uruguay. Ethnobiology and Conservation 7(4): 1-34.

Cavechia, L. A., M. Cantor, A. Begossi, and N. Peroni. 2014. Resource-use patterns in swidden farming communities: Implications for the resilience of cassava diversity. Human Ecology 42(4): 605-616.

Chebataroff, J. and M. E. Zavala. 1975. Relieve del Uruguay. Revista Uruguaya de Geografía. Segunda Serie 3: 2-47.

Cunningham, A. B. 2001. Applied ethnobotany. People, wild plant use and conservation. WWF, UNESCO, Royal Botanic Garden.

Curbelo, C. 2003. Analogy in historical archaeology. The case of San Francisco de Borja del Yi. The SAA Archaeological Record 3(4): 23.

Diaz-Reviriego, I., L. González-Segura, A. Fernández-LLamazares, P. L. Howard, J. L. Molina, and V. Reyes-García. 2015. Social organization influences the exchange and species richness of medicinal plants in Amazonian homegardens. Ecology and Society 21(1): 1. https://doi.org/10.5751/ES-07944-210101.

Dormann, C. F., J. Fründ, N. Blüthgen, and B. Gruber. 2009. Indices, graphs and null models: Analyzing bipartite ecological networks. The Open Ecology Journal 2009(2): 7-24.

Dormann, C. F., O. Schweiger, P. Arens, I. Augenstein, S. Aviron, D. Bailey, J. Baudry, R. Billeter, R. Bugter, R. Bukacek, F. Burel, M. Cerny, R. D. Cock, G. D. Blust, R. DeFilippi, T. Diekotter, J. Dirksen, W. Durka, P. J. Edwards, M. Frenzel, R. Hamersky, F. Hendrickx, F. Herzog, S. Klotz, B. Koolstra, A. Lausch, D. L. Coeur, J. Liira, J. P. Maelfait, P. Opdam, M. Roubalova, A. Schermann-Legionnet, N. Schermann, T. Schmidt, M. J. M. Smulders, M. Speelmans, P. Simova, J. Verboom, W. V. Wingerden, and M. Zobel. 2008. Prediction uncertainty of environmental change effects on temperate European biodiversity. Ecology Letters 11(3): 235-244.

Ferreira Júnior, W. S., A. H. Ladio, and U. P. d. Albuquerque. 2011. Resilience and adaptation in the use of medicinal plants with suspected anti-inflammatory activity in the Brazilian Northeast. Journal of Ethnopharmacology 138(1): 238-252. 
Ferreira Júnior, W. S., A. Nascimento, M. Alves Ramos, P. M. Medeiros, G. T. Soldati, F. R. Santoro, V. Reyes-García, and U. Albuquerque. 2015. Resilience and adaptation in socialecological systems. In: Evolutionary ethnobiology, eds. U. P. Albuquerque, P. M. Medeiros, and A. Casas, 105-119. New York: Springer.

Gaoue, O. G., M. A. Coe, M. Bond, G. Hart, B. C. Seyler, and H. McMillen. 2017. Theories and major hypotheses in ethnobotany. Economic Botany 71(3): 269-287.

Gavin, M. C., J. McCarter, A. Mead, F. Berkes, J. R. Stepp, D. Peterson, and R. Tang. 2015. Defining biocultural approaches to conservation. Trends in Ecology and Evolution 30(3): 140145.

González, L. R. and S. Rodríguez Varese. 1990. Guaraníes y paisanos. Impacto de los indios misioneros en la formación del paisanaje. Montevideo: Editorial Nuestra Tierra.

Hamilton, A. and K. Plenderleith. 2003. Compiled for WWF (Lead Organisation for the Consultation). Global Strategy for Plant Conservation. Convention on Biological Diversity. Stakeholder Consultation on Target 4.

Henrich, J. and J. Broesch. 2011. On the nature of cultural transmission networks: Evidence from Fijian villages for adaptive learning biases. Philosophical Transactions of the Royal Society B 366(1567): 1139-1148.

Hewlett, B. S. and L. L. Cavalli-Sforza. 1986. Cultural transmission among Aka Pygmies. American Anthropologist, New Series 88(4): 922934.

Hilborn, R. and M. Mangel. 1997. The ecological detective confronting models with data. Princeton University Press.

Hilgert, N. I. 2009. La salud en las Yungas. ¿Cuáles son los principales problemas según la medicina tradicional y la formal? In: Avances sobre plantas medicinales andinas. Argentina, eds. N. D. Vignale and M. L. Pochettino, 1-43. Jujuy, Argentina, RISAPRET/CYTED.S.S.

ISE. 2014. Codigo de Ética-International Society of Ethnobiology. http://www.ethnobiology.net.

Johnson, J. B. and K. S. Omland. 2004. Model selection in ecology and evolution. Trends in Ecology and Evolution 19(2): 101-108.

Kareiva, P. and M. Marvier. 2015. Conservation science: Balancing the needs of people and nature. Roberts and Co.

Kottek, M., J. Grieser, C. Beck, B. Rudolf, and F. Rubel. 2006. World map of the Köppen-Geiger climate classification updated. Meteorologische Zeitschrift 15(3): 259-263.

Lagos-Witte, S., O. L. Sanabria-Diago, P. Chacón, and R. García-Víquez. 2011. Manual de herramientas etnobotánicas relativas a la conservación y el uso sostenible de los recursos vegetales: Una contribución de la Red Latinoamericana de Botánica a la Implementación de la Estrategia Global para la Conservación de las Especies Vegetales hacia el logro de las metas 13 y 15 . Editorial Santiago, Red Latinoamericana de Botánica, Chile.

Leonti, M. 2011. The future is written: Impact of scripts on the cognition, selection, knowledge and transmission of medicinal plant use and its implications for ethnobotany and ethnopharmacology. Journal of Ethnopharmacology 134(3): 542-555.

Lozada, M., A. H. Ladio, and M. Weigandt. 2006. Cultural transmission of ethnobotanical knowledge in a rural community of northwestern Patagonia, Argentina. Economic Botany 66(4): 374-385.

Maffi, L. 2005. Linguistic, cultural, and biological diversity. Annual Review of Anthropology 34(1): 599-617.

2007. Biocultural diversity and sustainability In: The SAGE handbook on environment and society, eds. J. Pretty, A. Ball, T. Benton, J. Guivant, D. Lee, D. Orr, M. Pfeffer, and H. Ward, 267-277. SAGE Publications Ltd.

Martínez, M. R., M. L. Pochettino, M. A. Crivos, C. Remorini, and A. Sy. 2006. Gathering and circulation of medicinal plants in a pluricultural context (Misiones, Argentina). Proceedings of the IVth International Congress of Ethnobotany (ICEB 2005) August 2005: 107-114.

Mathez-Stifel, S., R. Brandt, S. Lachmuth, and S. Rist. 2012. Are the young less knowledgeable? Local knowledge of natural remedies and its transformations in the Andean Highlands. Human Ecology 40(6): 909-930.

Medeiros, P. M. and U. P. Albuquerque. 2015. Use patterns of medicinal plants by local populations. In: Evolutionary Ethnobiology, eds. U. P. Albuquerque, P. M. Medeiros and A. Casas, 163-174. Switzerland: Springer.

Medeiros, P. M. and U. P. Albuquerque, D. B. Oliveira Abreu, T. C. da Silva, W. Soares Ferreira Junior, M. Alves Ramos, and A. H. Ladio. 2016. What drives the use of natural products for medicinal purposes in the context 
of cultural pluralism? European Journal of Integrative Medicine 8(4): 471-477.

Medeiros, P. M., G. T. Soldati, N. L. Alencar, I. Vandebroek, A. Pieroni, N. Hanazaki, and U. P. Albuquerque. 2012. The use of medicinal plants by migrant people: Adaptation, maintenance, and replacement. Evidence-Based Complementary and Alternative Medicine 2012: 1-11.

Mello, M. A. R., F. M. D. Marquitti, P. R. J. Guimaraes, E. K. V. Kalko, P. Jordano, and M. A. M. Aguiar. 2011. The missing part of seed dispersal networks: Structure and robustness of bat-fruit Interactions. PLos One 6(2): e17395.

Memmott, J., N. M. Waser, and M. V. Price. 2004. Tolerance of pollination networks to species extinctions. Proceedings of the Royal Society B 271(1557): 2605-2611.

Müller, J. G., R. Boubacar, and I. D. Guimbo. 2015. The "how" and "why" of including gender and age in ethnobotanical research and community-based resource management. Ambio 44: 67-78.

Newman, M. E. J. 2010. Networks. An introduction. New York: Oxford University Press.

Nolla, S. G. and M. de Vargas. 2010. Diagnóstico socioeconómico zona URBAL-RIVERA, Uruguay. Programa Urbal Pampa, Uruguay.

Noy, C. 2008. Sampling knowledge: The hermeneutics of snowball sampling in qualitative research. International Journal of Social Research Methodology 11(4): 327-344.

Pascual, M. and J. A. Dunne. 2006. Ecological networks: Linking structure to dynamics in food webs. New York: Oxford University Press.

Pi Hugarte, R. 2014. Los indios del Uruguay. Banda Oriental, Montevideo.

Pochettino, M. L. and C. Eyssartier. 2014. Los saberes botánicos ocultos en la pluri/multi/interculturalidad (zonas urbanas de Argentina), eds. T. R. S. Silva, C. W. N. Moura, L. C. L. Lima, and F. A. R. Santos, 277-284. Botânica na América Latina: Conhecimento, interação e difusão. Sociedade Botânica do Brasil, Salvador.

Quilan, M. B. and R. J. Quilan. 2007. Modernization and medicinal plant knowledge in a Caribbean horticultural village. Medical Anthropology Quarterly 21(2): 169-192.

R Core Team. 2017. R: A language and environment for statistical computing. R Foundation for Statistical Computing, Vienna, Austria. http:// www.R-project.org.
Ramirez, C. R. 2007. Ethnobotany and the loss of traditional knowledge in the twenty-first century. Ethnobotany Research and Applications 5: 245-247.

Rendell, L., R. Boyd, and S. A. Suárez. 2010. Why copy others? Insights from the social learning strategies tournament. Science 328(5975): 208-213.

Reyes-García, V., M. Guèze, A. C. Luz, J. PanequeGálvez, M. J. Macía, M. Orta-Martínez, J. Pino, and X. Rubio-Campillo. 2013. Evidence of traditional knowledge loss among a contemporary indigenous society. Evolution and Human Behavior 34(4): 249-257.

Richards, S. A. 2005. Testing ecological theory using the information theoretic approach: Examples and cautionary results. Ecology 86: 2805-2814.

Rodríguez-Miranda, A. 2010. La frontera UruguayBrasil y el desarrollo local. Nóesis, Revista de Ciencias Sociales y Humanidades 19(37): 1651.

- 2015. Dinámicas sectoriales y desarrollo territorial en economías locales interiores. El caso de Rivera en Uruguay. Economía, Sociedad y Territorio XV(47): 217-250.

Rubel, F. and M. Kottek. 2010. Observed and projected climate shifts 1901-2100 depicted by world maps of the Köppen-Geiger climate classification. Meteorologische Zeitschrift 19(2): 135-141.

Santoro, F. R., W. S. Ferreira Júnior, T. A. d. S. Araújo, A. H. Ladio, and U. P. Albuquerque. 2015. Does plant species richness guarantee the resilience of local medical systems? A perspective from utilitarian redundancy. PLos One 10(3): e0119826.

Santoro, F. R., A. L. B. Nascimento, G. T. Soldati, W. S. Ferreira Júnior, and U. P. Albuquerque. 2018. Evolutionary ethnobiology and cultural evolution: Opportunities for research and dialog. Journal of Ethnobiology and Ethnomedicine 14(1): 1-14.

Soldati, G. T. 2013. Transmissao de conhecimiento: Origem social das informacoes e da evolucao cultural. In: Etnobiología. Bases ecológicas e evolutivas, ed. U. P. Albuquerque, 37-61. Recife/PE, NUPEEA.

2015. Knowledge transmission: The social origin of information and cultural evolution. In: Evolutionary Ethnobiology, eds. U. P. Albuquerque, P. M. Medeiros, and A. Casas, 89104. Switwerland: Springer. 
Soldati, G. T. and U. P. Albuquerque. 2016. Are the evolutionary implications of vertical transmission of knowledge conservative? Ethnobiology and Conservation 5(2016): 1-9.

Sousa, D. C. P. d., G. T. Soldati, J. M. Monteiro, T. A. d. S. Araújo, and U. P. Albuquerque. 2016. Information retrieval during free listing is biased by memory: Evidence from medicinal plants. PLos One 11(11): e0165838.

Soutullo, A., C. Clavijo, and J. A. MartínezLanfranco. 2013. Especies prioritarias para la conservación en Uruguay. Vertebrados, moluscos continentales y plantas vasculares. Montevideo: SNAP/DINAMA/MVOTMA y DICYT/ MEC.

Suárez, M. E. 2014. Etnobotánica wichí del bosque xerófito en el Chaco semiárido salteño. $1^{\text {a }}$ edition. Don Torcuato: Autores de Argentina, Buenos Aires.

Vandebroek, I. and M. J. Balick. 2012. Globalization and loss of plant knowledge: Challenging the paradigm. PLos One 7(5): e37643.

WHO. 2013. World Health Organization. Traditional medicine strategy 2014-2023. WHO Library Cataloguing-in-Publication Data, Hong Kong SAR, China.

Zank, S. and N. Hanazaki. 2016. Healing faith: Knowledge, learning and social relationships of healers from Araripe plateau, Brazil. Ethnobiology and Conservation 5: 3. https://doi.org/10. 15451/ec2016-6-5.3-1-15.

. 2017. The coexistence of traditional medicine and biomedicine: A study with local health experts in two Brazilian regions. PLos One 12(4): e0174731. 